\title{
Accuracy of Sonographic Identification of Suprascapular Nerve at Supraclavicular Fossa: A Cadaveric Study
}

\author{
Precisión de la Identificación Ecográfica del Nervio Supraescapular \\ en la Fosa Supraclavicular: Un Estudio Cadavérico
}

\author{
Naraporn Maikong1,2; Perada Kantakam ${ }^{1,2}$; Prangmalee Leurcharusmee ${ }^{3}$; \\ Apichat Sinthubua ${ }^{2,4} \&$ Pasuk Mahakkanukrauh ${ }^{2,4}$
}

\begin{abstract}
MAIKONG, N.; KANTAKAM, P.; LEURChARUSMEe, P.; SINTHUBUA, A. \& MAHAKKANUKRAUH, P. Accuracy of sonographic identification of suprascapular nerve at supraclavicular fossa: A cadaveric study. Int. J. Morphol., 39(5):1473-1479, 2021.

SUMMARY: Sonographic identification of suprascapular nerve (SSN) is essential for diagnosis of suprascapular neuropathy and ultrasound-guided suprascapular nerve block. This study aims to demonstrate the accuracy of identification of SSN at supraclavicular region by ultrasonography in fresh cadavers. Ninety-three posterior cervical triangles were examined. With ultrasonography, SSN emerging from the upper trunk of brachial plexus was identified and followed until it passed underneath the inferior belly of omohyoid muscle. Sonographic visualization of SSN in supraclavicular fossa was recorded. Then, cadaveric dissection was performed to determine the presence or absence of SSN. An agreement between sonographic identification and direct visualization was specified and categorized the following three patterns: "correctly identified" (pattern I), "incorrectly identified" (pattern II), and "unidentified" (pattern III). The identification of SSN using sonography was correct in almost $90 \%$. The diameter of SSN with pattern I was the largest compared to those of other two patterns. In pattern I, SSN ran laterally from the upper trunk of brachial plexus and passed underneath the inferior belly of omohyoid muscle. Therefore, SSN was easily identified under ultrasonography. In pattern II, nerve identified by ultrasonography was literally the dorsal scapular nerve.In pattern III, SSN was unable to be identified because of its anatomical variation. The accuracy of ultrasonographic identification of SSN at supraclavicular fossa is high and the key sonoanatomical landmarks are the lateral margin of brachial plexus and the inferior belly of omohyoid muscle. The anatomical variants of SSN are reasons of incorrect or unable identification of SSN under ultrasonography.
\end{abstract}

KEY WORDS: Suprascapular nerve; Supraclavicular region; Sonography; Cadaveric study.

\section{INTRODUCTION}

Sonoanatomy of the suprascapular nerve $(\mathrm{SSN})$ is essential for the diagnosis of suprascapular neuropathy (Bilfeld et al., 2017) and ultrasound-guided suprascapular nerve block (SSNB), which is an analgesic technique and relieves pain control for the proximal arm or arthroscopic shoulder surgery (Chan \& Peng, 2011; Malheiro et al., 2020; Siegenthaler et al., 2012).

The SSN derives from the upper trunk of the brachial plexus, which commonly receives nerve fibers from the ventral rami of the $\mathrm{C} 5$ and $\mathrm{C} 6$ nerve roots, and periodically obtains additional fibers from those of the $\mathrm{C} 4$ nerve. The SSN is a mixed nerve that conveys sensory as well as motor innervations (Agur \& Dalley, 2017; Basta et al., 2020). The
SSN supplies approximately $70 \%$ of the glenohumeral joint, mostly on the posterosuperior aspect. Also, it contributes to the acromioclavicular joint, coracoacromial ligament, coracoclavicular ligament, and subacromial bursa. The muscles innervated by the SSN are the supraspinatus and infraspinatus muscles (Agur \& Dalley; Tran et al., 2019; Malheiro et al.). The course of the SSN when it travels across the supraclavicular fossa varies. Generally, the SSN passes via the posterior cervical triangle and locates underneath the inferior belly of the omohyoid muscle. The SSN passes through the suprascapular fossa via the suprascapular notch. It runs underneath the superior transverse scapular ligament and gives branches to supply the supraspinatus and infraspinatus muscles (Agur \& Dalley; Basta et al.).

\footnotetext{
${ }^{1}$ Ph.D. Program in Anatomy, Department of Anatomy, Faculty of Medicine, Chiang Mai University, Chiang Mai, Thailand.

${ }^{2}$ Department of Anatomy, Faculty of Medicine, Chiang Mai University, Chiang Mai, Thailand.

${ }^{3}$ Department of Anesthesiology, Faculty of Medicine, Chiang Mai University, Chiang Mai, Thailand

${ }^{4}$ Excellence in Osteology Research and Training Center (ORTC), Chiang Mai University, Chiang Mai, Thailand.
} 
From a literature review, identification of the SSN under sonography has been divided into two locations which are the suprascapular and the supraclavicular regions. The SSN in the suprascapular area could not be reliably identified because the nerve is small and located deep to the supraspinatus muscle. Therefore, the nerve location in the suprascapular fossa is specified using surrounding bony landmarks (Chan \& Peng). Alternatively, identification of the SSN in the supraclavicular region is more feasible because the nerve lies superficially in the posterior cervical triangle and just underneath the inferior belly of the omohyoid muscle (Siegenthaler et al.; Battaglia et al., 2014; Rothe et al., 2014; Laumonerie et al., 2018). To date, published articles concerning the identification of the SSN in the supraclavicular fossa using ultrasound guidance are lacking and limited to a small sample size (Battaglia et al.; Bilfeld et al.). This study aims to demonstrate the accuracy of identification of the SSN at the supraclavicular region by ultrasonography in fresh cadavers.

\section{MATERIAL AND METHOD}

The study was permitted by the Research Ethics Committee, Faculty of Medicine, Chiang Mai University, Thailand (Ethics approval number: ANA-2563-07177). From March to July 2020, 48 fresh adult cadavers donated for research were obtained from the Department of Anatomy, Faculty of Medicine, Chiang Mai University, Thailand. The cadavers with a history of previous surgery or pathology at the supraclavicular region, the brachial plexus, and the shoulder girdle were excluded.

Ultrasonography performance. An anesthesiologist (PL) with more than five years of experience in ultrasound-guided regional anesthesia performed the sonography to identify the SSN in the supraclavicular fossa. The cadavers were supinely placed, positioning the shoulder neutrally and the neck on the contralateral side. The linear array ultrasound transducer with high-frequency (6 to13 MHz, LOGIQ F8, GE Healthcare, Wisconsin, USA) was placed at the supraclavicular region in a transverse plane. The brachial plexus between the anterior scalene and the middle scalene muscles was visualized, and the C5-C6 nerve roots (the upper trunk) were traced upward to the corresponding transverse processes. Subsequently, the transducer was moved distally in a craniocaudal direction to identify the SSN (in a short axis) emerging from the brachial plexus' upper trunk. The SSN was followed under ultrasonography until it passed underneath the omohyoid muscle' inferior belly. Within this location, the anesthesiologist informed the presence or absence of the SSN from ultrasonographic visualization.
Cadaveric dissection. The skin incision was performed along the anterior margin of the sternocleidomastoid muscle and over the clavicle from the sternal end to the acromial end. The skin flap was retracted laterally. The platysma muscle and the investing layer of the deep cervical fascia were removed. The inferior belly of the omohyoid muscle was observed across the posterior cervical triangle. After that, the pre-vertebral cervical fascia was dissected to visualize the brachial plexus located between the anterior and the middle scalene muscles. The upper trunk of the brachial plexus and the SSN were identified and preserved. The location of the SSN where it separated from the upper trunk was recorded and the diameter of the SSN was measured by Vernier Caliper.

Data collection. During the ultrasonography performance, a visualization of the SSN in the supraclavicular fossa under sonography, whether the SSN was identified or unidentified, was recorded. During the cadaveric dissection, a presence or absence of the SSN located underneath the inferior belly of the omohyoid muscle and laterally to the upper trunk was recorded. The accuracy of the identification of the SSN under sonography compared to the direct visualization was graded into these three patterns: "correctly identified" (pattern I), "incorrectly identified" (pattern II), and "unidentified" (pattern III). The anatomy of the SSN of the pattern II and III was explained in detail to demonstrate possible reasons of the incorrectly identified and unidentified SSN.

Statistical analysis. The descriptive statistic is summarized as percentages, mean \pm standard deviation (SD), minimum, and maximum values. The STATA 16 software (StataCorp LLC, TX, USA) was used to analyze the relationship of the probability of correctly identified SSN and the SSN's diameter. The level of statistical significance is considered as a $\mathrm{p}$-value $\leq 0.05$.

\section{RESULTS}

The current study examined 93 posterior cervical triangles (47 left and 46 right sides) from 48 fresh adult cadavers (29 males and 19 females) with a mean age of 74.22 \pm 12.19 years

The results in Table I showed that the identification of the SSN using sonography was correct in almost $90 \%$. The diameter of the SSN with the pattern I was the largest compared to those of the other two patterns.

In pattern I, when the SSN passed underneath the inferior belly of the omohyoid muscles, it ran laterally from 
MAIKONG, N.; KANTAKAM, P.; LEURCHARUSMEE, P.; SINTHUBUA, A. \& MAHAKKANUKRAUH, P. Accuracy of sonographic identification of suprascapular nerve at supraclavicular fossa: A cadaveric study. Int. J. Morphol., 39(5):1473-1479, 2021.

Table I. The accuracy of identification of the SSN under sonography and diameter of the SSN.

\begin{tabular}{|c|c|c|c|c|c|}
\hline & \multirow{2}{*}{$\begin{array}{l}\text { Identify of SSN } \\
\text { by sonography }\end{array}$} & \multirow{2}{*}{$\begin{array}{c}\text { Accuracy of SSN } \\
\text { by dissection }\end{array}$} & \multirow{2}{*}{$\mathrm{N}=93(\%)$} & \multicolumn{2}{|c|}{ Diameter SSN } \\
\hline & & & & Mean $\pm \mathrm{SD}(\mathrm{mm})$ & $\operatorname{Min}-\operatorname{Max}(\mathrm{mm})$ \\
\hline Pattern I & identified & correctly interpret & $82(88.17)$ & $1.81 \pm 0.38$ & $1.10-2.81$ \\
\hline Pattern II & identified & incorrectly interpret & $5(5.38)$ & $1.51 \pm 0.23$ & $1.14-1.73$ \\
\hline Pattern III & unidentified & N/A & $6(6.45)$ & $1.47 \pm 0.42$ & $0.96-1.93$ \\
\hline
\end{tabular}

SSN; suprascapular nerve, N; number of cases, N/A; not applicable

the upper trunk of the brachial plexus. Therefore, it was easily identified under ultrasonography. In other words, the inferior belly of the omohyoid muscle and the upper trunk of the brachial plexus were reliable sonoanatomical landmarks for identification of the SSN. (Figs. 1a,b).

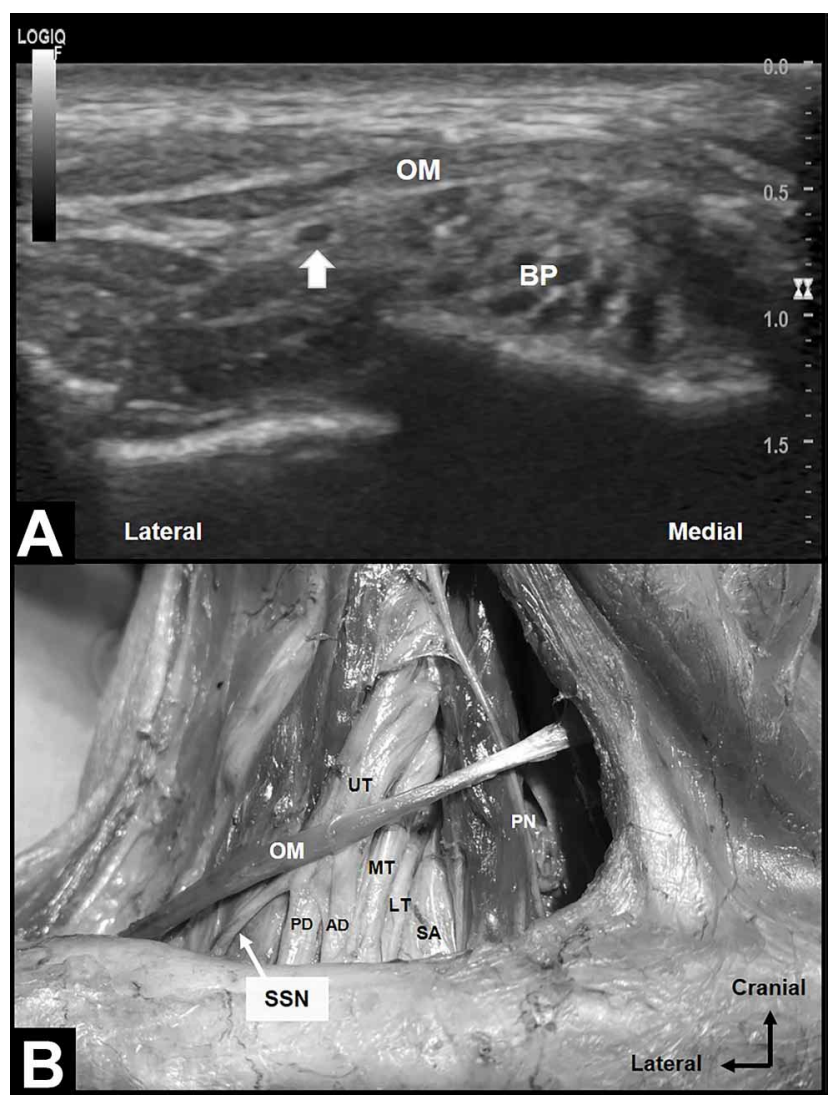

Fig. 1. Illustration of sonographic visualization and cadaveric dissection of the pattern I. A. The suprascapular nerve (SSN) (white arrow) was identified by sonography. B. The SSN was presented laterally from the upper trunk (UT) of the brachial plexus (BP) and underneath the inferior belly of omohyoid muscle (OM). AD; anterior division, LT; lower trunk, MT; middle trunk, PD; posterior division, $\mathrm{PN}$; phrenic nerve, $\mathrm{SA}$; subclavian artery.

The SSN was incorrectly identified under sonography (pattern II) in 5 out of 93 cases. After dissection, these incorrectly identified SSNs were the dorsal scapular nerve (DSN).The DSN emerged from the C5 nerve root close to

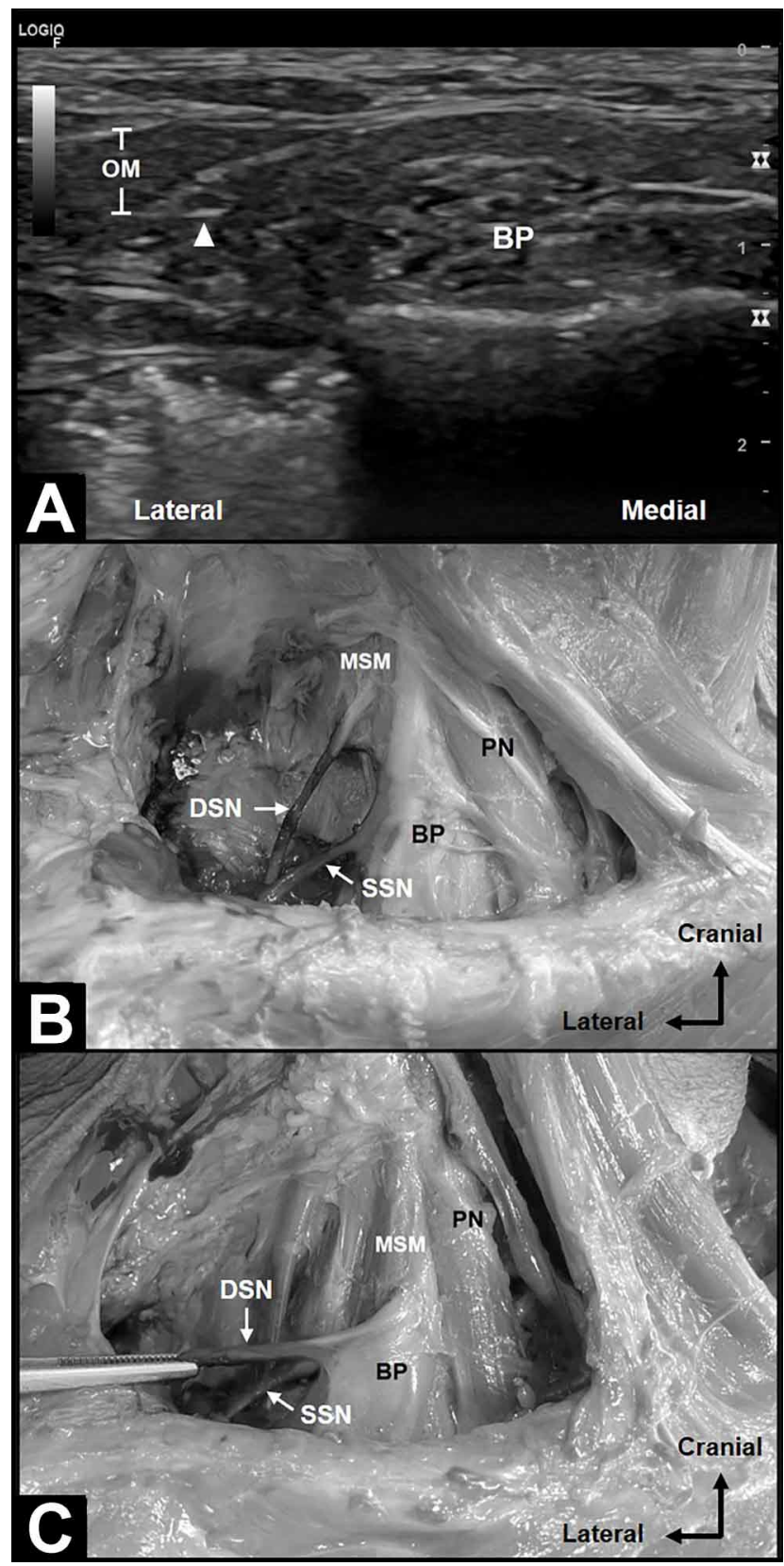

Fig. 2. Illustration of sonographic visualization and cadaveric dissection of the pattern II. A. The suprascapular (SSN) (white arrow) was identified by sonography. B, C. The dorsal scapular nerve (DSN) was misinterpreted as the SSN, B. Piercing type of DSN, C. Anterior type of DSN. BP; brachial plexus, MSM; middle scalene muscle, $\mathrm{OM}$; inferior belly of omohyoid muscle, $\mathrm{PN}$; phrenic nerve. 
the SSN and the DSN travelled parallel and superficial to the SSN.The course of the DSN in association with the middle scalene muscle (MSM) was divided into two types, the piercing, and anterior types. The descriptive anatomical data of pattern II was reported in Table II (Figs. 2a-c).

The potential reasons for the unidentified SSN (pattern III) were 1) the size of the SSN was small and unable to be identified under sonography, 2) the SSN emerged dorsal (instead of lateral) to the upper trunk of the brachial plexus and covered with a thick layer of fatty tissue, 3) the SSN emerged too distally and unable to be identified at the level

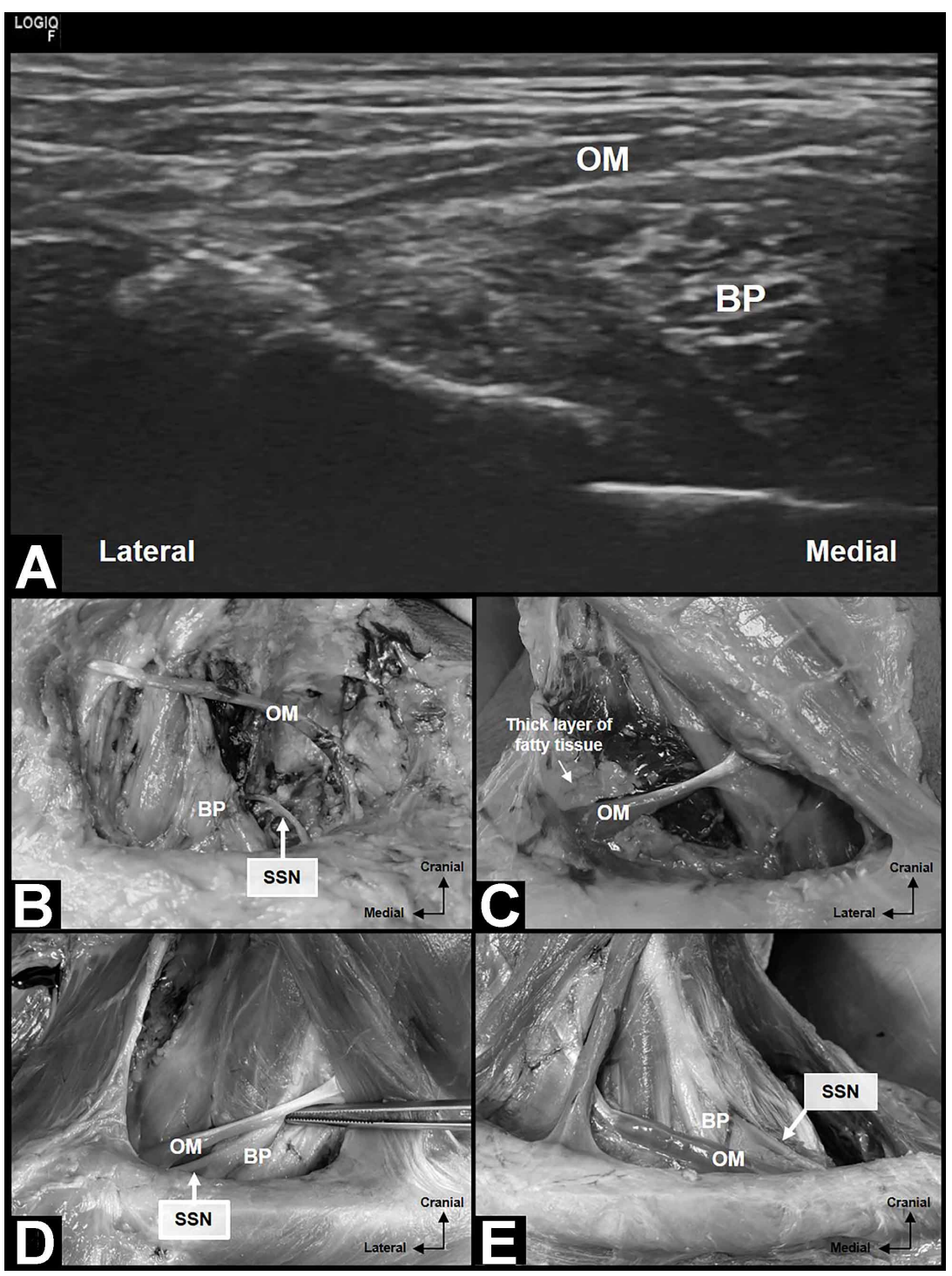

Fig. 3. Illustration of sonographic visualization and cadaveric dissection of the pattern III. a The suprascapular nerve (SSN) was not identified by sonography. $b$ The SSN was small. c The SSN and the upper trunk of the brachial plexus were covering with a thick layer of fatty tissue. $d$ The SSN emerged behind the clavicle. e The SSN attached to the upper trunk of the brachial plexus. BP; brachial plexus, OM; inferior belly of omohyoid muscle. of the inferior belly of the omohyoid muscle, and 4) the SSN attached to the upper trunk of the brachial plexus. The descriptive anatomical data of pattern III was shown in Table II (Figs. 3a-e).

The small diameter of SSN was a notable factor of unidentified SSN under sonography. From the regression analysis, with every $1 \mathrm{~mm}$ increase of the SSN's diameter, the probability of correct identification of the SSN raised by $31 \%(95 \% \mathrm{CI} ; 5.9-62.1 \%, \mathrm{P}=0.013)$.

\section{DISCUSSION}

The findings of this study demonstrated that the SSN at the supraclavicular region was correctly identified by ultrasonography in almost $90 \%$ of cadavers as reported in Table I. The knowledge was essential in the clinical settings; for instance, diagnosis of the suprascapular neuropathy (Bilfeld et al.) and ultrasound-guided SSNB (Chan \& Peng; Siegenthaler et al.; Malheiro et al.).

Identification of the SSN under ultrasonography has recently reported that the visuality of the SSN was better in the supraclavicular fossa $(81 \%)$ than that in the suprascapular fossa $(36 \%)$ in healthy volunteers (Siegenthaler et al.). Similarly, a prior study demonstrated that the supraclavicular portion was simpler to be defined than the scapular portion in healthy volunteers. Thus, a practical approach to identify the SSN is performing ultrasonography at the supraclavicular fossa (Bilfeld et al.).

Several methods of sonographic identification of the SSN at the supraclavicular fossa have been described. Tracing the SSN's origination from the upper trunk of the brachial plexus was defined as the "ski lift" technique (Lapegue et al., 2014). Referring to this technique, the SSN was positioned superficially in the supraclavicular fossa. The origin of the SSN was able to be visualized in all healthy volunteers and $90 \%$ of cadavers 


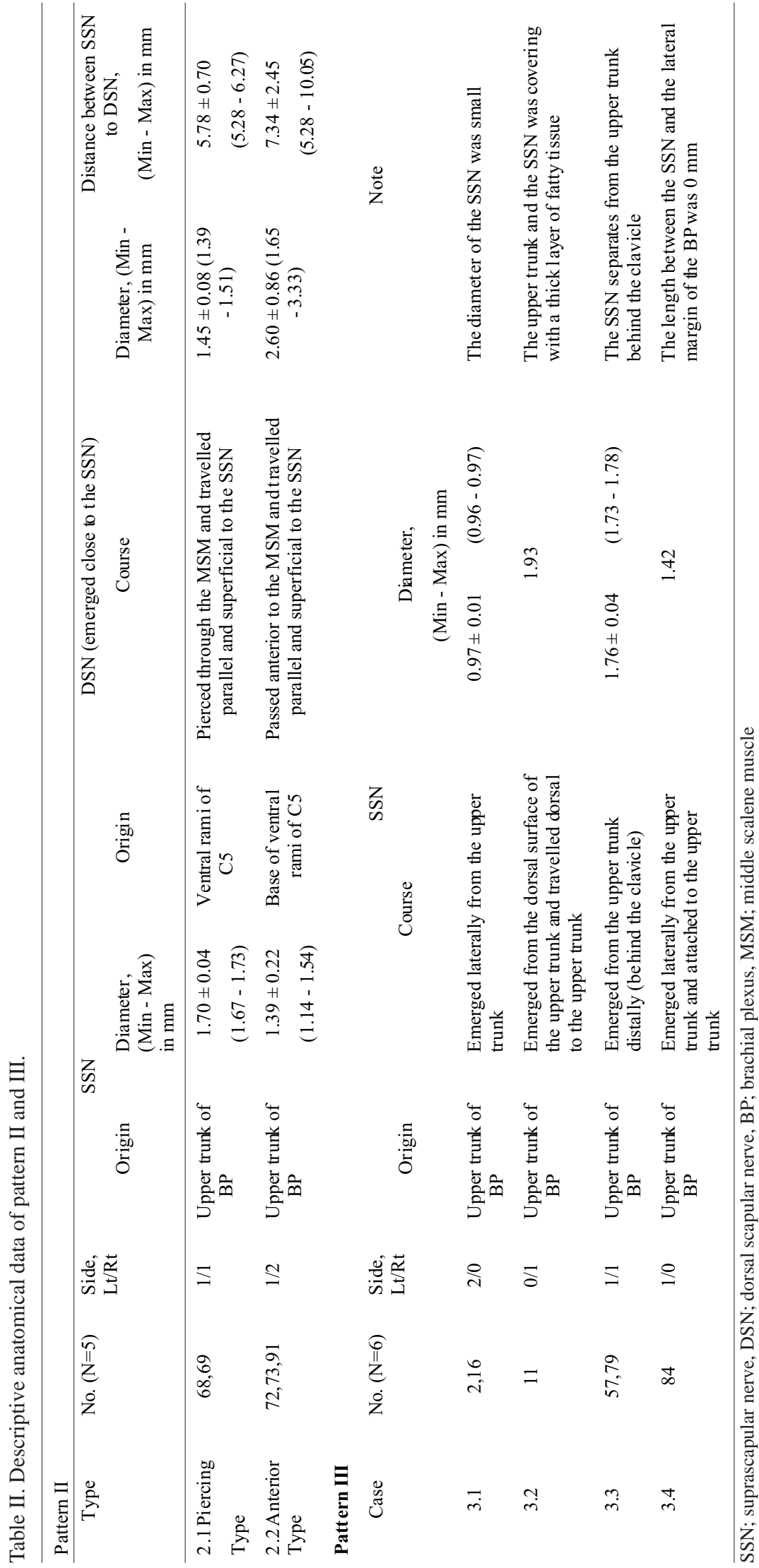

(Laumonerie et al., 2017). Besides, the technique using the inferior belly of the omohyoid muscle as the landmark of SSN identification has been described (Battaglia et al.). The possibility of SSN visualization using this technique was 90-96\% (Rothe et al.; Ko et al., 2017). These previously reported results were similar to our study in that the SSN at the supraclavicular region was correctly identified in $90 \%$ of cases. Therefore, the crucial ultrasonographic landmarks to identify the SSN are as follows: First, the SSN emerges from the upper trunk of the brachial plexus and crosses laterally within the posterior cervical triangle. Second, the inferior belly of the omohyoid muscle in long-axis view underneath the targeting SSN (Battaglia et al.; Lapegue et al.; Maikong et al., 2020).

Our study reported that the SSN was incorrectly identified (pattern II) in approximately $5 \%$ as shown in Table I. The reason for these results was the variation of the DSN courses in the supraclavicular fossa. In the majority of individuals, the DSN emerges from the C5 nerve root and is sometimes contributed by $\mathrm{C} 4$ to $\mathrm{T} 1$ nerve roots. The DSN pierces the MSM and runs posteriorly the posterior scalene, levator scapulae muscles, and anteriorly the serratus posterior superior muscle to innervate the rhomboid major and minor muscles, and sometimes the levator scapulae muscle (Tubbs et al., 2015; Bishop \& Varacallo, 2020). In our study, the DSNs that was misinterpreted as the SSN originated from the C5 nerve root and emerged near the location of the SSN where it branched out from the upper trunk of the brachial plexus. These DSNs sometimes travelled superficially and parallel the SSN to innervate the previously described muscles. In other words, because of the close proximity and homogenous courses of the DSN and the SSN, they are possibly misinterpreted under ultrasonographic identification. Also, our results revealed the relationship between the DSN and the MSM and reported two types of DSN variant; the piercing type (the DSN pierces through the MSM) and the anterior type (the DSN 
passes anterior to the MSM) as shown in Table II. Previous reports by Tetsu et al. (2018) and Nguyen et al. (2016) established that the incidences of piercing type were shown in 95 of 140 sides $(67.9 \%)$ and 17 of 23 sides $(74 \%)$, respectively. Our study reported that the mean diameter of DSNs with piercing and anterior type were 1.45 and $2.60 \mathrm{~mm}$, respectively whereas Jack et al. (2020) was measurable 3.7 $\mathrm{mm}$ from 18 cadaveric specimens.

There were $6 \%$ of cases that the SSN could not be identified (pattern III) by sonography, as shown in Table I. Typically, the SSN emerged laterally inside the posterior cervical triangle at the supraclavicular fossa and travelled underneath the inferior belly of the omohyoid muscle to the suprascapular notch (Gray, 2019; Basta et al.). Four variants of the unidentified SSN were described in our study. Detailed variants of pattern III were described as follows as shown in Table II: First, the diameter of SSN was small. Also, the probability of correct identification of the SSN raised by 31 $\%$ when the diameter increases by $1 \mathrm{~mm}$. The previous literatures have been reported that the SSN ranged from 2-3 $\mathrm{mm}$ in diameter (Siegenthaler et al.; Laumonerie et al., 2018; Gray). Second, the SSN separated dorsally from the upper trunk of the brachial plexus, instead of emerging laterally. Third, the SSN emerged from the upper trunk of the brachial plexus too distally and it located behind the clavicle. Consistent with the results of Emamhadi et al. (2016) shown that the anatomical variation of the SSN formation may be contributed from the posterior division of the upper trunk in $12.5 \%$. Therefore, at the level of the inferior belly of the omohyoid muscle, the SSN was unidentified. Fourth, the SSN attached to the upper trunk of the brachial plexus. In contrast to the prior study, the length from the SSN to the brachial plexus was approximately $8 \mathrm{~mm}$ (range $4-15 \mathrm{~mm}$ ) (Siegenthaler et al.; Maikong et al.). Therefore, these anatomical variants lead to the inability of the SSN identification under sonography.

There are a few limitations in this study. The ultrasonographic identification of the SSN was performed by a highly experienced anesthesiologist and our results might not be applied to the novice hands. Also, cadavers were not able to turn the neck in a fully rotated position and the SSN ultrasonographic identification would be easier in human subjects with head fully rotated to the contralateral side.

\section{CONCLUSION}

The high accuracy of ultrasonographic identification of SSN at the supraclavicular fossa suggests that this approach is effective for diagnosis the suprascapular neuropathy and ultrasound-guided SSNB. The key sonoanatomical landmarks are the lateral margin of the brachial plexus and the inferior belly of the omohyoid muscle. The anatomical variants of the SSN are reasons of incorrect or unable identification of the SSN under ultrasonography.

\section{ACKNOWLEDGEMENTS}

This study was funded by Faculty of Medicine, Chiang Mai University, Chiang Mai, Thailand (Grant Agreement No.014-2564) and we would like to thank the Excellence in Osteology Research and Training Center (ORTC) with partially supported by Chiang Mai University, Chiang Mai, Thailand.

MAIKONG, N.; KANTAKAM, P.; LEURCHARUSMEE, P.; SINTHUBUA, A. \& MAHAKKANUKRAUH, P. Precisión de la identificación ecográfica del nervio supraescapular en la fosa supraclavicular: un estudio cadavérico. Int. J. Morphol., 39(5):14731479, 2021.

RESUMEN: La identificación ecográfica del nervio supraescapular (NSE) es esencial para el diagnóstico de neuropatía supraescapular y bloqueo del nervio supraescapular mediante la ecografía. Este estudio tiene como objetivo demostrar la precisión de la identificación de NSE en la región supraclavicular por ecografía en cadáveres frescos. Se examinaron noventa y tres triángulos cervicales posteriores. Se identificó el NSE emergente de la parte superior del tronco del plexo braquial con la ecografía, y se siguió hasta su trayecto por debajo del vientre inferior del músculo omohioideo. Se registró la visualización ecográfica del NSE en la fosa supraclavicular. Luego, se realizó disección cadavérica para determinar la presencia o ausencia de NSE. Se especificó un acuerdo entre la identificación ecográfica y la visualización directa y se categorizaron los siguientes tres patrones: "identificado correctamente" (patrón I), “identificado incorrectamente" (patrón II) y "no identificado" (patrón III). La identificación de NSE mediante ecografía fue correcta en casi el $90 \%$. El diámetro del NSE con el patrón I fue el más grande en comparación con los de los otros dos patrones. En el patrón I, NSE corría lateralmente desde la parte superior del tronco del plexo braquial y pasaba por debajo del vientre inferior del músculo omohioideo. Por lo tanto, el NSE se identificó fácilmente mediante ecografía. En el patrón II, el nervio identificado por ecografía era literalmente el nervio escapular dorsal; en el patrón III, el NSE no pudo ser identificado debido a su variación anatómica. La precisión de la identificación ecográfica del NSE en la fosa supraclavicular es alta y los puntos de referencia sonoanatómicos clave son el borde lateral del plexo braquial y el vientre inferior del músculo omohioideo. Las variantes anatómicas de NSE son razones de identificación incorrecta o incapaz de NSE bajo ecografía.

PALABRAS CLAVE: Nervio supraescapular; Región supraclavicular; Ecografía; Estudio cadavérico. 


\section{REFERENCES}

Agur, A. M. \& Dalley, A. F. Grant's Atlas of Anatomy. 14th ed. Philadelphia, Lippincott Williams \& Wilkins, 2017.

Basta, M.; Sanganeria, T. \& Varacallo, M. Anatomy, Shoulder and Upper Limb, Suprascapular Nerve. Treasure Island (FL), StatPearls Publishing, 2020.

Battaglia, P. J.; Haun, D. W.; Dooley, K. \& Kettner, N. W. Sonographic measurement of the normal suprascapular nerve and omohyoid muscle. Man. Ther, 19(2):165-8, 2014.

Bilfeld, M. F.; Lapègue, F.; Sans, N.; Gandois, H. C.; Laumonerie, P. \& Larbi, A. Ultrasonography study of the suprascapular nerve. Diagn. Interv. Imaging, 98(12):873-9, 2017.

Bishop, K. N. \& Varacallo, M. Anatomy, Shoulder and Upper Limb, Dorsal Scapular Nerve. Treasure Island (FL), StatPearls Publishing, 2020.

Chan, C. W. \& Peng, P. W. H. Suprascapular nerve block: a narrative review. Reg. Anesth. Pain Med., 36(4):358-73, 2011.

Emamhadi, M.; Chabok, S. Y.; Samini, F.; Alijani, B.; Behzadnia, H.; Firozabadi, F. A. \& Reihanian, Z. Anatomical variations of brachial plexus in adult cadavers; a descriptive study. Arch. Bone. Jt. Surg., 4(3):253-8, 2016.

Gray, A. T. Suprascapular Nerve Block (Anterior Approach Above the Clavicle). In: Gray, A. T. Atlas of Ultrasound-Guided Regional Anesthesia. 3rd ed. Philadelphia, Elsevier, 2019. pp.89-92.

Jack, A. S.; Shah, V. \& Jacques, L. G. Foraminal origin of the dorsal scapular nerve: an anatomical study. World Neurosurg., 144:e341-6, 2020.

Ko, K. P.; Kang, D. H. \& Shin, B. K. The proximal approach in an ultrasoundguided suprascapular nerve block. J. Korean Orthop. Assoc., 52(6):5218, 2017.

Lapegue, F.; Faruch-Bilfeld, M.; Demondion, X.; Apredoaei, C.; Bayol, M. A.; Artico, H.; Chiavassa-Gandois, H.; Railhac, J. J. \& Sans, N. Ultrasonography of the brachial plexus, normal appearance and practical applications. Diagn. Interv. Imaging, 95(3):259-75, 2014.

Laumonerie, P.; Ferré, F.; Cances, J.; Tibbo, M. E.; Roumiguié, M.; Mansat, P. \& Minville, V. Ultrasound-guided proximal suprascapular nerve block: A cadaveric study. Clin. Anat., 31(6):824-9, 2018.

Laumonerie, P.; Lapègue, F.; Chantalat, E.; Sans, N.; Mansat, P. \& Faruch, M. Description and ultrasound targeting of the origin of the suprascapular nerve. Clin. Anat., 30(6):747-52, 2017.

Maikong, N.; Leurcharusmee, P.; Sinthubua, A. \& Mahakkanukrauh, P. Identification of suprascapular nerve as related with omohyoid muscle, brachial plexus and clavicle in supraclavicular fossa for selective suprascapular nerve block. Int. Med. J., 27(1):88-91, 2020.

Malheiro, N. S.; Afonso, N. R.; Pereira, D.; Oliveira, B.; Ferreira, C. \& Cunha, A. C. Efficacy of ultrasound guided suprascapular block in patients with chronic shoulder pain: retrospective observational study. Braz. J. Anesthesiol., 70(1):15-21, 2020.

Nguyen, V. H.; Liu, H. H.; Rosales, A. \& Reeves, R. A cadaveric investigation of the dorsal scapular nerve. Anat. Res. Int., 2016:4106981, 2016.

Rothe, C.; Steen-Hansen, C.; Lund, J.; Jenstrup, M. T. \& Lange, K. H. W. Ultrasound-guided block of the suprascapular nerve - a volunteer study of a new proximal approach. Acta Anaesthesiol. Scand., 58(10):122832, 2014.

Siegenthaler, A.; Moriggl, B.; Mlekusch, S.; Schliessbach, J.; Haug, M.; Curatolo, M. \& Eichenberger, U. Ultrasound-guided suprascapular nerve block, description of a novel supraclavicular approach. Reg. Anesth. Pain Med., 37(3):325-8, 2012.

Tetsu, S.; Terayama, H.; Qu, N.; Yamazaki, H.; Sakamoto, R.; Tanaka, O.; Suyama, K.; Takenaka, M.; Suzuki, T. \& Sakabe, K. Anatomical variants of dorsal scapular nerve in relation to the middle scalene muscle in Japanese population. Medicine (Baltimore), 97(47):e13349, 2018.

Tran, J.; Peng, P. W. H. \& Agur, A. M. R. Anatomical study of the innervation of glenohumeral and acromioclavicular joint capsules: implications for image-guided intervention. Reg. Anesth. Pain Med., 2019. DOI: https:/ /www.doi.org/10.1136/rapm-2018-100152
Tubbs, R. S.; Goodrich, D.; Watanabe, K. \& Loukas, M. Anatomic Landmarks for Selected Nerves of the Head, Neck, and Upper and Lower Limbs. In: Tubbs, R. S.; Rizk, E.; Shoja, M. M.; Loukas, M.; Barbaro, N. \& Spinner, R. J. (Eds.). Nerves and Nerve Injuries. San Diego, Academic Press, 2015. pp 575-88.

Corresponding author:

Prof.PasukMahakkanukrauh, MD

Excellence in Osteology Research and

Training Center (ORTC)

Department of Anatomy

Chiang Mai University

Faculty of Medicine

Chiang Mai University

Chiang Mai

THAILAND

E-mail: pasuk034@gmail.com

Received: 20-06-2021

Accepted: 22-07-2021 